УДК 662.8 (4Укр):006.3

(C) 2012

Чурілов Д. Г., аспірант*,

Калініченко В. М., кандидат сільськогосподарських наук,

Калініченко А. В., доктор сільськогосподарських наук, професор,

Малинська Л. В., старший викладач

Полтавська державна аграрна академія

\title{
ДЕРЖАВНЕ РЕГУЛЮВАННЯ РИНКУ ТВЕРДОГО БІОПАЛИВА ЯК ОДИН ІЗ ЧИННИКІВ ЗБАЛАНСОВАНОГО ПРИРОДОКОРИСТУВАННЯ
}

Рецензент - доктор сільськогосподарських наук, професор П. В. Писаренко

\begin{abstract}
Розглянуто можливості використання біомаси у вигляді паливних транул як альтернативи традиційним енергоносіям для забезпечення збалансованого природокористування. Проведено аналіз існуючих стандартів на виготовлення паливних гранул у краӥнах Свропи та США, а також основних вимог до иьього виду твердого біопалива. Представлено відмінності між діючими й попередніми нормативами. Показано економічну доичільність та обтрунтовано необхідність введення державних стандартів якості для виробників біопалива в Украӥні, зокрема для паливних транул.
\end{abstract}

Ключові слова: альтернативні джерела енертії, пелети, паливні транули, біопаливо, стандарти паливних транул EN plus.

Постановка проблеми. Визначення шляхів, способів і перспектив використання біомаси в якості альтернативного енергоносія $€$ однією 3 найбільш актуальних проблем сьогодення. Серед різноманітних напрямів розвитку цього типу енерггозабезпечення найбільш розповсюдженим $\epsilon$ спалювання біомаси. Для підвищення ефективності цього процесу у світі широко застосовують різні способи попередньої переробки біомаси, наприклад, іiі пелетування.

Аналіз основних досліджень і публікацій, у яких започатковано розв'язання проблеми. За даними багатьох джерел, пелети (паливні гранули) характеризуються як глибоко перероблений i екологічно чистий вид палива [1-9]. Вони є реальною альтернативою кам'яному вугіллю і нафті, поскільки за своїми теплотворними характеристиками не поступаються викопним джерелам енергіï [2]. Екологічність твердого біопалива, доведена значною кількістю науковців, у багато разів перевищує традиційні варіанти опалення $[1,3,5]$. Крім того, ще однією з його переваг $є$ більша теплотворна здатність у порівнянні, наприклад, із відходами деревообробних підприємств або сільськогосподарського виробництва, що не пройшли попередньої обробки перед спалюванням [2].

Україна - агропромислова країна, що володіє величезним незадіяним ресурсом різноманітної сировини для випуску як деревних, так і сільськогосподарських пелет. Деякі автори зазначають, що наша багата на ресурси країна, на жаль, займає далеко не перші позиції серед країн світу iз впровадження інноваційних технологій, у тому числі й у біоенергетиці $[3,6,9]$. Враховуючи значний обсяг світового виробництва (понад 15 млн тонн деревних пелет щорічно), український ринок виробництва біопалива знаходиться ще на стадії розвитку: за оцінками аналітиків компаніï D\&P Consult, обсяг виробництва пелет у нашій країні за підсумками 2008 року становив близько 190-200 тис. т [2].

Мета дослідження - обгрунтування доцільності введення державних норм стандартизації для виробників паливних гранул в Україні.

Матеріали і методи досліджень. Дослідження базується на матеріалах наукових праць вітчизняних і зарубіжних авторів, світовому досвіді та практиці використання твердого біопалива у різних країнах світу. Методи досліджень, що використані при написанні статті, грунтуються на діалектиці та комплексному підході до вивчення економіко-екологічних проблем.

Результати дослідження. Історія виникнення пелет бере свій початок із 1947 року. Власник лісопильного господарства, американець Рудольф Гуннерман, не маючи технічної освіти, винайшов простий спосіб для вивезення відходів власного виробництва. Для зменшення транспортних витрат винахідливий підприємець вирішив пресувати деревні відходи, адже в такому вигляді їх легше складати й економічно доцільніше транспортувати. За кілька десятків років

* Керівник-доктор сільськогосподарських наук, професор А. В. Калініченко 
про пелети знову згадали, проте вже в якості енергетично привабливого товару [6]. Європа, передусім іiі північна частина, має на своїй території значні лісові масиви й технологічно розвинену деревопереробну промисловість. Тому, згадавши практику Гуннермана та його пелети, європейські країни, в першу чергу Швеція, у середині 80-х років XX ст. знову почали використовувати винайдений кілька десятиліть тому спосіб пресування відходів. Саме цей час і вважається початком нової ери в паливній галузі [2].

У минулому сторіччі прийнятною та дешевою сировиною для опалення вважалися в першу чергу дрова та вугілля, й лише після них - йшли нафта та газ. Однак розвіданих запасів чорного та блакитного золота, що мають достатньо низьку собівартість видобутку, за різними оцінками, залишилося на кілька десятків років [3]. Ураховуючи постійне подорожчання енергоносіїв у світі та можливість розвитку енергетичної кризи, провідні країни світу все активніше заохочують підприємців до розвитку альтернативної енергетики. Завдяки конкуренції серед фірмвиробників і монтажних компаній якісно покращується ринок енергоощадних товарів та підвищується культура енергоефективного використання ресурсів.

Сьогодні сегмент ринку використання альтернативних носіїв теплової енергії має широкий розмах у європейських країнах. У СС було прийнято директиву щодо активізації розвитку відновлювальної енергетики, відповідно до якої країни Євросоюзу до 2020 року зобов'язані збільшити частку відновлювальних джерел енергії (ВДЕ) при видобутку тепла та електроенергії до $20 \%$ [3]. Уже до кінця 2012 року очікується, що за рахунок ВДЕ в СС буде отримуватися близько $12 \%$ енергіï, до того ж понад $5 \%$ - із твердої біомаси [3]. Темпи зростання цього порівняно молодого (не більше 10-12 років) ринку стабільні: щорічно його обсяг у світі збільшується на 15-20 \%. У Великобританії, наприклад, до 2013 року річне використання паливних гранул збільшиться до 5 млн тонн. Нідерланди планують протягом 2012 р. ввести в експлуатацію низку нових «зелених» електростанцій, збільшивши обсяг споживання пелет до 4,5 млн т на рік. За таких темпів до 2020 року щорічна потреба в даному виді палива в Європі зросте до 80-135 млн тонн [4].

Нині ЄС є головним імпортером пелет у світі, а виробництво гранул сконцентроване передусім у країнах, багатих лісовими ресурсами, таких як США та Канада, а також країнах північної Свро- пи (Швеція, Фінляндія, Німеччина) [2]. Однак, у зв'язку зі збільшенням споживання експортери все частіше стикаються 3 необхідністю пошуку додаткової сировини. Обсяги відходів деревини, що використовувалися до сьогодні стають недостатніми. До того ж криза скоротила обсяги лісозаготівельної галузі й деревообробки в усьому світі, через що значно підвищилися ціни на сировину. Основні шляхи вирішення проблеми: вирощування швидкоростучих дерев, імпорт тирси та принципово новий продукт - агропелети. Сировиною для виробництва останніх є солома, лушпиння соняшнику і гречки, полова рису, деревна частина стебел льону, ріпаку, конопель та ін.

Європейські країни намагаються стимулювати людей до переходу на цей вид палива. У Німеччині, наприклад, кожна родина, що встановить у себе котел для спалювання біомаси, отримує від держави дотацію в розмірі 1550 євро плюс по 50 євро за кожен кВт потужності котла [8].

На основі вивчення літературних джерел нами було виділено наступні основні екологічні фактори, що призводять до стимулювання використання пелет:

- зменшення парникового ефекту - вуглекислий газ, що виділяється в процесі горіння пелет, кваліфікується як «нейтральний». Деревина виділяє рівно стільки $\mathrm{CO}_{2}$, скільки отримала в процесі росту (закритий вуглецевий обмін). При спалюванні вугілля чи нафти виділяється $\mathrm{CO}_{2}$, накопичений за мільйони років, що збільшує концентрацію $\mathrm{CO}_{2}$ в атмосфері. У свою чергу, збільшення концентрації $\mathrm{CO}_{2}$ призводить до парникового ефекту;

- зменшення кислотних дощів - використання пелет сприяє зменшенню викидів двоокису сірки $\left(\mathrm{SO}_{2}\right)$, що є головною причиною кислотних дощів. Використовуючи пелети як паливо, ми цим самим зменшуємо кислотні опади та зберігаємо ліси, яким кислотні дощі завдають найбільшої шкоди;

- зменшення небезпеки транспортування - забруднення навколишнього середовища відбувається практично безперервно через пробоїни в корпусах танкерів, аварії на газопроводах, електростанціях, у разі перевезення автомобільним i залізничним транспортом. Процес транспортування пелет набагато простіший і безпечніший. У випадку аварії їх досить нескладно збирати, а те, що залишиться, не завдасть довкіллю шкоди, адже у процесі їх виробництва не використовуються хімічні сполуки.

В європейських країнах у 90-х роках відбулася перша хвиля стандартизації для підприємств- 
виробників паливних гранул [1]. У результаті цього процесу було розроблено та прийнято наступні стандарти:

- у Німеччині - DIN 51731, або DINplus;

- в Австрії - ONORM M7135;

- у Великобританії - «The British BioGen Code of Practice for biofuel (pellets)»;

- у Швейцарії - SN 166000;

- у Швеції - SS 187120.

У США зараз є чинним Standard Regulations \& Standards for Pellets in the US: The PFI (pellet) [1]. На основі цього стандарту в країні виготовляються пелети двох категорій: преміум і стандарт. У гранулах «преміум» вміст золи повинен бути не більше $1 \%$, а в «стандарт» не більше $3 \%$.

Більшість країн в Європі й поза ії межами, які $\epsilon$ постачальниками паливних гранул, до першого кварталу 2010 року орієнтувалися на стандарт DINplus, сертифікація за яким об'єднує норми DIN 51731 та ONORM M7135 [1]. Значна увага приділяється таким критеріям, як теплотворна здатність, вологість, стиранність, зольність та граничний вміст різних хімічних елементів.

Стрімкий розвиток виробництва та споживання паливних гранул, а також зростання кількості суміжних представників цього ринку, стали передумовою для введення в СС на початку 2010 р. нових норм щодо якості паливних гранул. Вимоги за новим стандартом EN 14961-2, введеного в дію 1 січня 2010 р., були не тільки посилено, а й доповнено новими критеріями [7]. За новими стандартами пелети розподіляються за якісними характеристиками на три класи. Найбільш жорсткі вимоги встановлені для паливних гранул першого сорту A1. Максимально допустима зольність для таких гранул становить 0,5 \% (пелети 3 хвойних порід дерева) і 0,7 \% (із листяних порід). Такі гранули рекомендовано до використання у приватному секторі. Другий сорт паливних гранул А2 може бути вироблений із змішаних сортів дерев і мати зольність до $1 \%$. Пелети такого стандарту зазвичай використовуються у котельних широкого профілю. Так звані промислові гранули за новими нормами віднесені до третього сорту В і призначені для використання на потужних теплових станціях промислового типу.

За даними інтернет-ресурсу «Біоресурс Україна» [7] (див. табл.), можна провести порівняльний аналіз нових європейських стандартів паливних гранул EN plus iз колишнім німецьким стандартом DIN plus.

Порівнюючи табличні показники слід, на нашу думку, звернути увагу на зміни у нормі теплоти згорання. Зменшення мінімального значення у нових стандартах до 16,5 МДж/кг вказує на можливість використання гранул із сировини, яка раніше не мала цінності для енергетичного ринку. У нових стандартах обов'язковою характеристикою стає насипна маса паливних гранул та додається норма щодо температури плавлення золи.

Детально розглянувши питання можливості й доцільності прийняття єдиної системи державної сертифікації продукції, пов'язаної з переробкою відходів деревообробних та аграрних підприємств, із нашого погляду, виникає ціла низка проблем, пов'язаних із введенням контролю та стандартизації продукції в Україні.

Основні норми європейських стандартів на паливні гранули

\begin{tabular}{|c|c|c|c|c|c|}
\hline Норми якості & Од. виміру & DIN plus & EN plus $-\mathrm{A} 1$ & EN plus $-\mathrm{A} 2$ & $\mathrm{EN}-\mathrm{B}$ \\
\hline Діаметр & MM & $4-10$ & $6( \pm 1)$ & $6( \pm 1)$ & $6( \pm 1)$ \\
\hline Довжина & MM & $\leq 5 \times \mathrm{D}$ & $3,15 \leq \mathrm{L} \leq 40$ & $3,15 \leq \mathrm{L} \leq 40$ & $3,15 \leq \mathrm{L} \leq 40$ \\
\hline $\begin{array}{l}\text { Насипна } \\
\text { маса }\end{array}$ & $\kappa \Gamma / M^{3}$ & - & $\geq 600$ & $\geq 600$ & $\geq 600$ \\
\hline $\begin{array}{c}\text { Теплота } \\
\text { згорання }\end{array}$ & МДж/кг & $\geq 18$ & $\geq 16,5$ & $\geq 16,5$ & $\geq 16,0$ \\
\hline Вміст вологи & $\%$ & $\leq 10$ & $\leq 10$ & $\leq 10$ & $\leq 10$ \\
\hline $\begin{array}{c}\text { Стиранність* } \\
\text { /пил }\end{array}$ & $\%$ & $\leq 1$ & $\leq 1$ & $\leq 1$ & $\leq 1$ \\
\hline Твердість & $\%$ & $\geq 97,7$ & $\geq 97,5$ & $\geq 97,5$ & $\geq 97,5$ \\
\hline Зольність & $\%$ & $\leq 0,5$ & $\leq 0,7$ & $\leq 1,0$ & $\leq 3,0$ \\
\hline $\begin{array}{c}\text { Температура } \\
\text { плавлення золи }\end{array}$ & ${ }^{\circ} \mathrm{C}$ & - & $\geq 1200$ & $\geq 1100$ & $\geq 1100$ \\
\hline
\end{tabular}

Примітка. * Стиранність - це показник утворення дрібного пилу при транспортуванні за рахунок взаємного тертя гранул. 
Можна виділити кілька факторів, сприятливих для розвитку українського ринку.

По-перше, в структурі ринку виробництва біопалива на деревні гранули припадає близько 30-35 \% від загального виробництва. Значну ж частину займають пелети з лушпиння соняшнику та інших сільськогосподарських культур. Iз урахуванням зростаючого в Європі інтересу до пелет із відходів аграрного виробництва, наша країна має непогані перспективи у розвитку даної галузі.

По-друге, згідно зі статистичними даними, кількість гравців на українському ринку твердого біопалива за 4 останніх роки зросла у декілька разів [7]. Для порівняння: якщо у 2008 р. випуском пелет займалося близько двадцяти компаній, у 2009 р. їх кількість досягла сотні, а у 2011 р. кілька сотен. На нинішній і наступний рік сумарно в Україні заплановано будівництво ще декількох десятків заводів із виробництва деревних пелет i паливних гранул із соломи зернових культур [2].

Введення в Україні державних норм, що відповідатимуть новим європейським стандартам, збільшить довіру до вітчизняних виробників i допоможе перейти на якісно новий рівень продукції на внутрішньому ринку держави. Збільшення експорту паливних гранул в європейські країни стимулюватиме стрімкий розвиток виробництва екологічно чистого палива в Україні. Нині для експорту біопалива за кордон українські підприємства вимушені проходити перевірку своєї продукції за стандартами країни-споживача й лише після цього укладати контракти, що вимагає зайвих фінансових та часових затрат.

Однак, на жаль, окрім позитивних факторів можна виділити й негативні. «На сьогоднішній день ринок твердого біопалива в Україні відноситься до тих, що найбільш динамічно розвиваються у світі. Але незважаючи на масштабний запуск нових виробництв, якісної продукції на ринку вкрай мало, стверджує президент Асоціації учасників ринку альтернативних видів палива та енергії України (АПЕУ) Віталій Давій. - Україна сьогодні в основному випускає індустріальні пелети і брикети, які спалюються на ТЕЦ і ТЕС. Вимоги до якості такої продукції мінімальні, та й ціни на світових ринках на неї невисокі» [5].

Введення в Україні єдиних стандартів якості для паливних гранул має врегулювати безконтрольну переробку природних ресурсів. Організація єдиного державного контролюючого органу може стати першим кроком до підвищення енергоефективності споживання. Поліпшення якості паливних гранул призведе до використання технологічно досконалого теплового обладнання як у приватному секторі, так і в процесі промислового використання.

Технічний стан української промисловості, політичні й соціопсихологічні фактори не дозволяють ув повній мірі застосувати до України нещодавно прийнятий європейський стандарт EN 14961-2 [9]. Нові норми стосуються не лише виробників біопалива, але охоплюють значно ширший діапазон контролю якості товару - від переробки сировини та процесу виробництва до складування і транспортування через одного або декількох трейдерів до місця використання.

Отже, процес сертифікації будуть проходити не тільки підприємства-виробники гранул, а й транспортні та складські компанії, підприємства оптової й роздрібної торгівлі. На даний час такі комплексні заходи склали б непосильним тягарем для виробників твердого біопалива в Україні.

Саме через це (незважаючи на те, що прийняття нормативно-законодавчої бази та державних вимог у галузі виробництва твердого біопалива $€$ нагальною вимогою часу для нашої країни) такі заходи слід здійснювати поетапно й на ступеневій основі.

На першому етапі пропонується запровадити в Україні стандарти, аналогічні до німецьких норм DINplus, які б стосувалися виключно якості паливних гранул і приймалися за основу в багатьох європейських країнах до 1 січня 2010 року. Важливою є також розробка довгострокової державної програми, згідно з якою передбачатиметься поступове підвищення якості виготовленої продукції та встановлення нормативних вимог для суміжних галузей (перевезення, складування, трейдерство).

Такі заходи підвищать рівень конкурентоздатності продукції українських виробників на міжнародній арені й позитивно вплинуть на економічний стан країни.

\section{Висновки:}

1. 3 огляду на світові перспективи розвитку галузі виробництва твердого біопалива нормативно-правова база цього питання потребує врегулювання на державному рівні.

2. Введення єдиних норм для цієї галузі в Україні надасть можливість підприємствам випускати більш конкурентоздатну продукцію.

3. Контроль і врегулювання відносин у сфері виробництва пелет із біомаси сприятиме збалансованому використанню природних ресурсів. 


\section{БІБЛІОГРАФІЯ}

1. Древесные пеллеты / Официальный сайт кампании «ЭкоБиоТех» [Електронний ресурс]. Режим доступу $<$ http://ecobiotech.com.ua $>$

2. Інформаційний портал деревообробної галузі [Електронний ресурс]. - Режим доступу $<$ http://www.derevo.info $>$

3. Офіційний інтернет-портал Есо.com.ua (Промислова екологія) [Електронний ресурс]. - Режим доступу $<$ http://eco.com.ua $>$

4. Офіційний інтернет-ресурс Wood Fuel Wales [Електронний ресурс]. - Режим доступу $<$ http://www.woodfuelwales.org.uk $>$

5. Офіційний інтернет-ресурс Міністерства палива та енергетики України [Електронний ресурс]. - Режим доступу $<$ http://mpe.kmu.gov.ua $>$

6. Пеллеты / Официальный сайт кампании
«EKSPERA Biotrade« [Електронний pecypc]. Режим доступу $<$ http://biotoplivo.eu/pellets $>$

7. Производство пеллет / Официальный сайт кампании «Биоресурс Украина» [Електронний ресурс]. - Режим доступу <http://bioresource.com.ua $>$

8. Решения для биоэнергетики: техника, машины, оборудование для использования отходов, возобновляемые источники энергии / Официальный сайт кампании «Agro-T «[Електронний ресурс]. - Режим доступу <http://www.agro-t.de> 9. Сектор биотоплива / Електронный журнал енергосервисной компании «Экологические системы» [Електронний ресурс]. - №8, 2010. - Режим доступу <http://www.esco-ecosys.narod.ru/ frames/about journal.htm $>$ 